\title{
E-retailing Ethics in Egypt and Its Effect on Customer Repurchase Intention
}

\author{
Gomaa Agag and Ibrahim Elbeltagi \\ Plymouth Graduate School of Management, \\ Plymouth University, Mast House, Shepherd's Wharf, \\ 24 Sutton Rd, Plymouth, Devon, PL4 0HJ \\ \{gomaa.agag, i.elbeltagi\} @plymouth.ac.uk
}

\begin{abstract}
The theoretical understanding of online shopping behaviour has received much attention. Less focus has been given to the formation of the ethical issues that result from online shopper interactions with e-retailers. The vast majority of earlier research on this area is conceptual in nature and limited in scope by focusing on consumers' privacy issues. Therefore, the purpose of this paper is to propose a theoretical model explaining what factors contribute to online retailing ethics and its effect on customer repurchase intention. The data were analysed using variance-based structural equation modelling, employing partial least squares regression. Findings indicate that the five factors of the online retailing ethics (security, privacy, non- deception, fulfilment/reliability, and corporate social responsibility) are strongly predictive of online consumers' repurchase intention. The results offer important implications for e-retailers and are likely to stimulate further research in the area of e-ethics from the consumers' perspective.
\end{abstract}

Keywords: E-retailing, online retailing ethics, repurchase intention, structural equation modelling.

\section{Introduction}

The internet has come as a strong alternative way of physical commerce. The internet itself is a global phenomenon, with over 2,7billion users worldwide in 2013, up from 420 million in 2000 and 1 billion in 2005 [1]. In the developing world, 31\%of the population is online, compared with $77 \%$ in the developed world [1].The incredible growth of e-commerce presents ethical issues by the way Internet represents new environment for unethical behaviour [2]. Although many business are acknowledging the importance of e-commerce and online retailing activities, little attention has been given to the business community's perceptions of the ethicality of this new media [3].Given the latest technological developments in e-retailing, this paper advances our understanding of the ethical issues in the online retail context. In this respect we follow the call by [4].For internet researchers to make significant contribution to the retailing literature "by utilizing theories not frequently applied to internet issues as well as investigating antecedents variables heretofore overlooked". 
A number of studies have addressed consumers' ethical believes and practices [5, $6,7,8]$, as well as consumers' perceptions of retailers ethics $[9,10,11,12]$. Yet, little research has been conducted on the potential ethical issues regarding online retailing from the consumers' perspective. In addition, the vast majority of earlier research is conceptual in nature, and has primarily focused on privacy issues e.g., [13, 14, 15, 16, 17] ignoring other important ethical marketing issues surrounding the Internet such as deception and dishonesty $[3,18]$. The purpose of our study is to propose a theoretical model explaining what factors contribute to online retailing ethics and its effect on customer repurchase intention.

\section{$2 \quad$ Literature Review}

According to the Aristotelian moral philosophy tradition, the meaning of the word "ethics" is "human actions from the point of view of their rightness or wrongness" [19]. Ethics corresponds to "what is good?" [20], however there is not any universal answer to this question [21] "Marketing Ethics" could be defined as the standards of conduct and moral judgment applied to marketing practice or a code of morals for the marketing field [19]. There are many studies in the literature addressing various issues concerning marketing ethics $[22,23,24]$. However, previous researchers have tended to ignore other potential important ethical marketing issues pertaining to the internet, such as deception, dishonesty, and accuracy [25]. Though the CPEOR scale was developed in 2007, few studies e.g. [26, 27, 28, 29, 30] have examined the antecedents e.g. consumers' general internet expertise and consequences e.g. trust, perceived value, satisfaction, loyalty, and word-of-mouth of CPEOR. Further, it is particularly relevant to understand how consumers evaluate the ethics of their web sites in the face of competition between merchants and constantly rising consumer expectations [26]. Drawing on the above studies, in this research, online retailing ethics (ORE) is defined as consumers' perceptions about the integrity and responsibility of the company (behind the website) in its attempt to deal with consumers in a secure, confidential, fair and honest manner that ultimately protects consumers' interests.

\section{Theoretical Model and Research Hypotheses}

We expect ORE to be a higher-order construct composed of five dimensions. In particular, we conceive a second-order factor structure in which five distinct component factors (i.e., security, privacy, fulfilment, non-deception, and CSR) are the manifestation of a broader, more general and more abstract higher-order latent variable (ORE). This conceptualization is consistent with previous definitions of business ethics at highly abstract levels e.g., [31, 32, 33]. In such a second-order factorial structure, each factor can be considered a manifestation of ORE, and each item is a manifestation of its respective factor. Based on this reasoning, we propose the following hypothesis: 
Hypothesis 1: ORE is a second-order construct composed of five dimensions (i.e., security, privacy, fulfilment, non-deception, and CSR).

\subsection{ORE and Repurchase Intention}

Repurchase intention is defined here as the intention to repurchase a particular brand of product again. A buyer who has higher levels of trust of the salesperson and the manufacturer with which he/she has had experience is more likely to repurchase that brand than is the customer with lower levels of trust. Holden, (1990) found that one of the outcomes of both trust of the salesperson and trust of the company is purchasing loyalty. It is understood that if a customer buys from the same supplier again and is well disposed toward it affectively, he or she is really loyal to the provider $[34,35$, $36,37]$. In the financial services the main outcomes of the service will then influence the customer's attitude. But other aspects related to the perceived social behaviour of the provider can determine the final attitude too [38]. A review of the literature identified a number of studies on social programs that found positive effects of social and ethical business practices on customer attitudes toward the brand [39] with stronger identification with the company, greater brand purchase and greater intention to seek employment with the company [40]. In this sense, consumers are willing to actively support companies committed to cause-related marketing, environmentally friendly practices and ethics [41, 42]. Limbu, et al., (2011) pointed out that perceived ethics of an Internet retailer's website significantly affect consumers' trust and attitudes to the retailer's website that eventually have positive impacts on purchase and revisit intentions. The ORE is proposed to positively influence the customer's repurchase intentions. The following hypothesis is suggested regarding the impact of ORE on repurchase intention.

Hypothesis 2: As security increase, consumer repurchase intention will increase.

Hypothesis 3: As privacy increase, consumer repurchase intention will increase.

Hypothesis 4: As fulfilment increase, consumer repurchase intention will increase.

Hypothesis 5: As non-deception increase, consumer repurchase intention will increase.

Hypothesis 6: As CSR increase, consumer repurchase intention will increase.

\section{$4 \quad$ Method}

\subsection{Sample Selection and Data Collection}

To empirically test the hypotheses, we used a questionnaire survey. Data was collected from the American university in Egypt. Student samples have often been used in online shopping research e.g., [43, 44]. We obtained a usable sample of 280 students. Demographic details of the sample profile are provided in Table 1. 
Table 1. Sample profile

\begin{tabular}{|c|l|l|l|}
\hline Variable & Categories & Frequency & Percent \\
\hline Gender & Male & 155 & $55.0 \%$ \\
& Female & 125 & $45.0 \%$ \\
\hline Age & $<20$ & - & - \\
& $20<30$ & 180 & $64.0 \%$ \\
& $30>40$ & 80 & $28.5 \%$ \\
& $<40$ & 20 & $7.5 \%$ \\
\hline Monthly income & $£ 1,000$ or below & 125 & $44.5 \%$ \\
& $£ 1,001-2,000$ & 90 & $32.0 \%$ \\
& $£ 2,001-3,000$ & 50 & $18.0 \%$ \\
& $£ 3,001$ or above. & 15 & $5.5 \%$ \\
\hline Education & Bachelor degree & 10 & $3.5 \%$ \\
& Diploma & 20 & $7.0 \%$ \\
& Master or doctorate. & 250 & $89.5 \%$ \\
& Other & - & \\
\hline Frequency of online & $<3$ times & 212 & $76.0 \%$ \\
shopping within a & $4-6$ times & 31 & $11.0 \%$ \\
year & $7-9$ times & 26 & $9.0 \%$ \\
& $>10$ times & 11 & $4.0 \%$ \\
\hline Experience & $<2$ & 180 & $64.0 \%$ \\
& $2<5$ & 70 & $25.0 \%$ \\
& $>5$ & 30 & $11.0 \%$ \\
\hline
\end{tabular}

\subsection{Measurement Scales}

We used existing multi-item scales for the measurement of (Privacy, Security, Fulfilment/Reliability, and Non-deception). This scale developed by [26] and has four dimensions: security (5 items), privacy (4 items), non-deception (4 items) and fulfilment/reliability (4 items). All scales consisted of 5-point Likert questions, ranging from " 1 = strongly disagree" to " $5=$ strongly agree" ". CSR was measured using a scale adapted from [45] scale of "corporate social irresponsibility" and followed the conceptualization of [46]. Repurchase intention was measured using five items scale adapted from [47].

\section{$5 \quad$ Results}

\subsection{Descriptive Statistics}

A total of 280 respondents were surveyed online. Of these 280 participants, 155 were men $(55.0 \%)$ and 125 were women $(45.0 \%)$. The majority of respondents were aged 
between 20 and 30 (64.0\%), had post-graduate education (master and doctorate) $(89.5 \%)$, and had engaged in online shopping three times within the previous year $(82.0 \%)$. The most recent online shoppers experience for the majority of respondents was within the previous 2 years $(64.0 \%)$ and the most online shoppers income was $£ 1000$ or below $(44.5 \%)$. Table1 shows the respondent demographics.

\subsection{Measurement Model}

In contrast with LISREL, the partial least squares (PLS) method is an appropriate analytical tool in this case because it has minimal demands on measurement scales, sample size, and residual distributions [48]. The assessment of a measurement model should examine (1) individual item reliability, (2) internal consistency, and (3) discriminate validity (Barclay, Higgins, \& Thompson, 1995). This study employs the structural equation modelling tool WarpPLS (version 4.0) for confirmatory factor analysis to estimate the measurement model using WarpPLS analysis to test construct reliability and validity. The results in Table 2 show that composite reliabilities ranged from 0.891 to 0.917 , all exceeding 0.7 [52], and the AVE of each construct ranged from 0.651 to 0.701 , all exceeding 0.5 [48]. Table 2 shows that all indices fit with heuristics. Discriminate validity is tested in the measurement model analysis to determine the correlations between the latent variables and other constructs. The convergent and discriminant validity were assessed by checking whether the AVE (average variance extracted) of each construct is larger than its correlation with the other constructs, and whether each item had a higher loading on its assigned construct than on the other constructs $[53,54]$. The results indicate that the discriminate validity was achieved, as shown in Table 2.

Table 2. Results of composite reliability and convergent/discriminant validity testing

\begin{tabular}{|c|c|c|c|c|c|c|c|c|}
\hline \multirow[t]{2}{*}{ Construct } & \multirow[t]{2}{*}{ Reliability } & \multirow[t]{2}{*}{ AVE } & \multicolumn{6}{|c|}{ Correlations and square roots of AVEs. } \\
\hline & & & PV & $\mathrm{SC}$ & REL & $\mathrm{DEC}$ & CSR & REP \\
\hline PV & 0.891 & 0.672 & $(0.826)$ & & & & & \\
\hline SC & 0.904 & 0.701 & 0.815 & $(0.837)$ & & & & \\
\hline REL & 0.896 & 0.682 & 0.777 & 0.800 & $(0.822)$ & & & \\
\hline $\mathrm{DEC}$ & 0.912 & 0.676 & 0.748 & 0.774 & 0.665 & $(0.820)$ & & \\
\hline CSR & 0.917 & 0.651 & 0.770 & 0.779 & 0.728 & 0.803 & $(0.807)$ & \\
\hline REP & 0.874 & 0.662 & 0.803 & 0.793 & 0.763 & 0.797 & 0.712 & $(0.816)$ \\
\hline
\end{tabular}

Note: PV: privacy, SC: security, REL: reliability, DCE: non-deception, CSR: Corporate social responsibility and REP: repurchase intention. 


\subsection{Structural Model}

The model explains $81 \%$ of variance for the repurchase intention. H1 since we wanted to have stronger evidence of the existence of the five ethical dimensions, Following the method utilized by $[55,56]$, we performed CFA analyses using WarpPls 4.0 comparing several possible factor structures (see Table 3). We compared the fit of the six-factor model to that of a series of alternative models with fewer factors: five-factor model (privacy + security, non-deception, reliability, CSR, and repurchase intention) and four-factor model (privacy + security + reliability, non-deception, CSR, and repurchase intention) and three-factor (privacy + security + reliability, non-deception + CSR, and repurchase intention) and a twofactor model (privacy + security + reliability + non-deception + CSR, and repurchase intention). As shown in Table 3, the five factors model, one second-order factor fits the data much better than the other factor models. For example, the AARS difference between the proposed five-factor model and the others models is highly significant $(\mathrm{AARS}=0.758, \mathrm{p}<0.001)$.

Table 3. Summary results of models fit indices

\begin{tabular}{|lccccc|}
\hline Models & APC & ARS & AARS & AVIF & GOF \\
\hline five factors, & 0.168 & 0.773 & 0.758 & 2.653 & 0.742 \\
one second-order factor & & & & & \\
five factors & 0.187 & 0.713 & 0.708 & 2.851 & 0.702 \\
four factors & 0.217 & 0.706 & 0.702 & 2.949 & 0.689 \\
three factors & 0.261 & 0.707 & 0.704 & 3.191 & 0.687 \\
two factors & 0.321 & 0.694 & 0.691 & 3.364 & 0.674 \\
\hline
\end{tabular}

The overall fit measures suggest that the model is a plausible representation of the structures underlying the empirical data. The $\mathrm{APC}=(0.168, \mathrm{p}<0.001), \mathrm{ARS}=$ (0. 773, p<0.001), AARS $=(0.758, \mathrm{p}<0.001), \mathrm{AVIF}=(2.653)$, and $\mathrm{GOF}=(0.742)$. As long as the Average path coefficient (APC), the Average R squared (ARS), and the Average adjusted R-squared (AARS) are significant under 5\% level, and the average variance inflation factor (VIF) is lower than 5. As well as the geometric mean of the average communality (GOF) suggests a large effect size, the overall fit indices indicate a good fit of the model [57]; [58]. These findings suggest that ORE can be modelled as a second-order construct. This provides strong support for the five dimensions as aspects of ORE as a second-order construct, thus confirming Hypothesis 1. Further evidence for acceptance of the second-order factor structure is found in the variance explained by the structural equations. ORE as a second-order construct explains $81 \%$ of customer satisfaction, as opposed to $72 \%$ in the alternative. 


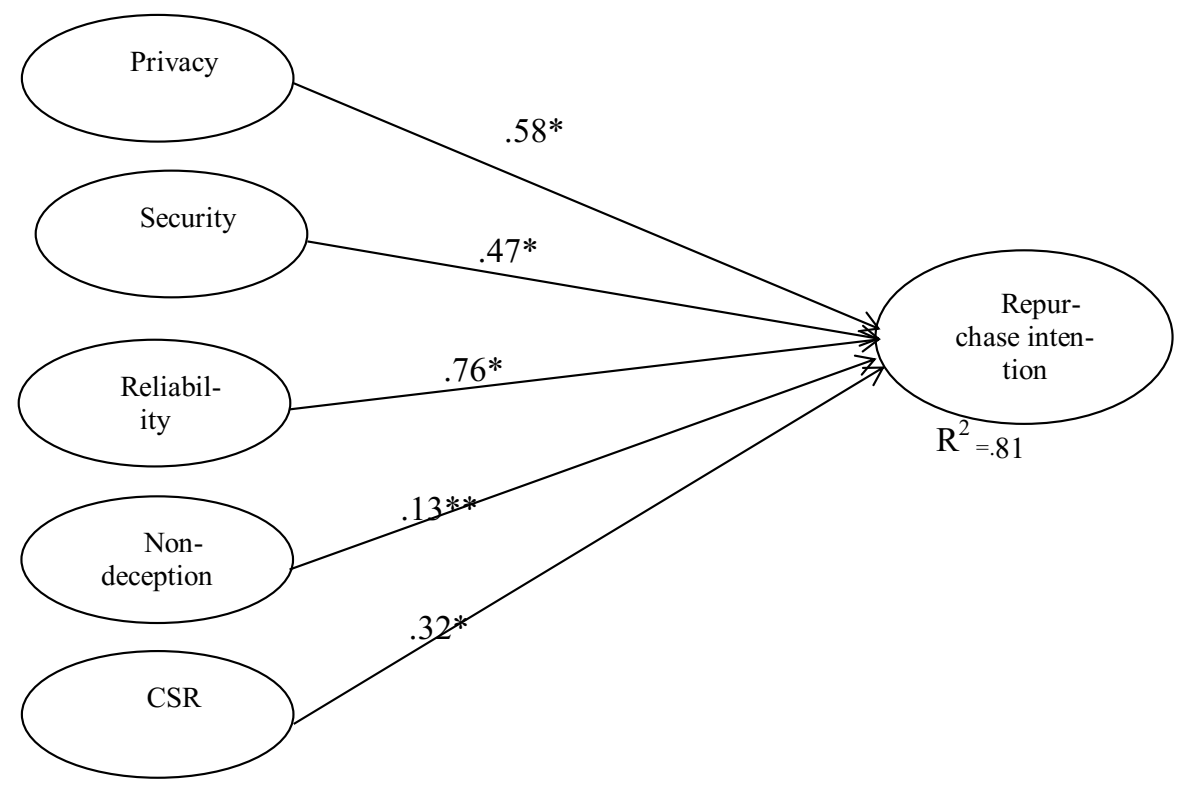

* Significant at the 0.01 level.

** Significant at the 0.05 level.

Fig. 1. PLS results of research model of main test $(n=310)$

$\mathrm{APC}=(0.168, \mathrm{p}<0.001), \mathrm{ARS}=(0.773, \mathrm{p}<0.001), \mathrm{AARS}=(0.758, \mathrm{p}<0.001)$, $\mathrm{AVIF}=(2.653)$, and $\mathrm{GOF}=(0.742)$.

$\mathrm{H} 2$ examines the effects of privacy on repurchase intention. Privacy is significantly related to repurchase intention $(\mathrm{B}=.58, \mathrm{p}<.01)$.

$\mathrm{H} 3$ examines the effects of security on repurchase intention. Security is significantly related to repurchase intention $(\mathrm{B}=.47, \mathrm{p}<.01)$.

$\mathrm{H} 4$ examines the effects of reliability on repurchase intention. Reliability is significantly related to repurchase intention $(\mathrm{B}=.76, \mathrm{p}<.01)$.

H5 examines the effects of non-deception on repurchase intention. Non-deception is significantly related to repurchase intention $(\mathrm{B}=.13, \mathrm{p}<.05)$.

H6 examines the effects of CSR on repurchase intention. CSR is significantly related to repurchase intention $(\mathrm{B}=.32, \mathrm{p}<.01)$.

The software calculates five fit indices which are meaningful in the context of variance-based SEM [57, 58]: average path coefficient (APC), average $\mathrm{R}^{2}$ (ARS), Average adjusted R-squared (AARS), average variance inflation factor (VIF), and geometric mean of the average communality (GOF). Their values are the following: $\mathrm{APC}=(0.168, \mathrm{p}<0.001), \mathrm{ARS}=(0.773, \mathrm{p}<0.001), \mathrm{AARS}=(0.758, \mathrm{p}<0.001), \mathrm{AVIF}=$ (2.653), and $\mathrm{GOF}=(0.742)$. 


\section{Discussion}

The aim of this study was to examine the impact of online retailing ethics on repurchase intention with the extending research model adapted from [26]. Data were collected in Egypt. The findings of the hypotheses testing of this study were as follows.

First, we confirmed that ORE is a multidimensional construct composed of five dimensions: security, privacy, fulfilment/reliability, non-deception, and CSR.

Second, the findings of this study show the direct effect of the five dimensions (security, privacy, fulfilment/reliability, non-deception, and CSR) on consumer repurchase intention. This result confirms the findings of previous studies that online retailing ethics significantly impacts the customer repurchase intention e.g. [26, 27, 28].

A key aspect of this multidimensional conceptualization is that privacy is important. Privacy is a great concern in modern society [59]. The American Marketing Association (AMA) Code of Ethics for Marketing on the Internet states that "information collected from customers should be confidential and used only for expressed purposes." This statement recommends that e-commerce companies comply with ethical principles and protect a consumer's privacy. The results of the current study also indicate that ORE involves privacy.

Security, the second dimension, is an important issue in contemporary online transactions [60]. Prior literature argued that technological protection and security statements are significant factors that can improve consumer-perceived security [61, $62,63]$. Our study suggests that consumers desire e-commerce companies to have technological protection and security statements. Thus, ORE includes security.

Fulfilment/reliability, suggests that ORE is also related to the service quality delivered by websites on which consumers shop online. Consistent with previous research $[64,65]$, our results show that online consumers want to receive the right quality and right quantity of items that they ordered within the time frame promised by the online retailers, and they expect to be billed accurately by them.

The existence of the fourth dimension, non-deception, indicates that consumers' concerns arising in traditional markets due to deceptive or manipulative advertising and sales practices are somewhat exacerbated in Internet commerce by the relatively unfamiliar and impersonal nature of the Web, where the lack of opportunities for face-to-face interactions reduces people's ability to detect deception [66]. For instance, in traditional retail settings, the detection of deception relies, amongst other things, on recognizing subtle changes in a person's non-verbal behaviours, such as eye contact and body movements [67].

Finally, CSR, Several studies have investigated how consumers perceive the social responsibility of retailers $[68,41]$. An international survey has been conducted on 211 scholars with expertise in business ethics. Each respondent was asked to identify the three most important issues that business ethics academia will face in the coming decade. The results suggest that the most important issues facing business ethics academia in the future will be the corporate social responsibility [69].

Fulfilment was the strongest predictor of repurchase intention. This adds further empirical evidence to previous results $[65,26]$. When shopping online, consumers are 
vulnerable. They worry that they will not receive the products or services exactly as they purchased. Consequently, consumer concerns about fulfilment are still a critical issue for online retailers [70]. Furthermore, privacy, followed by security, CSR and non-deception, had a strong influence on repurchase ignition Overall; these results are in line with several articles and reports e.g., [71, 72].

\section{Theoretical Contribution}

This study contributes to the literature in the following ways. First, the study provides empirical support for a comprehensive model of ORE composed of five multidimensional constructs that include security, privacy, fulfilment/reliability non-deception, and CSR. Several scales developed to measure online service quality tend to collapse privacy and security concepts into one dimension $[64,65]$. Prior research in the traditional marketplace addressing consumers' ethical perceptions has considered a limited number of dimensions. For example, in [73] study, the security/privacy dimension refers to: "security of credit card payments and privacy of shared information".

Second key contribution of the present study stems from the analysis of the effects of ORE on consumer repurchases intention. Overall, this is particularly relevant if we take into account the psychological distance theory. Several theories of interpersonal communication suggest physical proximity in communication fosters stronger bonds between the parties than communication that occurs remotely e.g., [27, 26]. The current study shows that ORE factors become a key means of fostering consumers' repurchase intention in a context where communications occur remotely.

\section{Implications for Practice and Future Research Directions}

Research suggests that ethics can play a critical role in the formation and maintenance of long-term relationships with customers [74]. In order to successfully operate a commercial website from an ethical perspective, online retailers need to understand how consumers' ethical perceptions are formed. The present study compiled a list of 23 items (grouped into five factors) that online retailers can use to assess such perceptions. These items would provide several hints to online retailers in terms of how to shape their customers' satisfaction and repurchase intentions.

We encourage future studies to use random sampling of general consumers. The ethics literature identifies some factors which influence ethical judgments of consumers (e.g., sex, age, and education). Such research could identify how each variable, individually and cooperatively, impacts consumer ethical evaluations of online retailing. We did not collect data from non-Internet shoppers because the focus of this study was online consumers referring to their latest purchase online. It may be an interesting extension, however, to test this conceptual model for other populations like non online consumers. 


\section{Conclusion}

Some researchers believe that a systematic empirical study of e-commerce ethical issues must be conducted from the consumers' perspective [26]. This study represents an initial step into examining of e-retailing ethics from the consumers' perspective and the understanding of its effects on consumer repurchases intention. The results offer important implications for e-retailers and are likely to stimulate further research in the area of e-ethics from the consumers' perspective.

\section{References}

1. Internet world stats, "Miniwatts," (2013), http: / /www. internetworldstats.com/stats.htm (accessed May 25, 2013)

2. Freestone, O., Michell, V.: Generation Y attitudes towards e-ethics and Internet - related misbehaviours. Journal of Business Ethics 54, 121-128 (2004)

3. Bush, V.S., Venable, B.T., Bush, A.: ethics and marketing on the Internet: practioners perceptions of societal, industry and companyconcerns. Journal of Business Ethics 23, 237248 (2000)

4. James, R.B., Rajiv, P.D.: The Theoretical Domains of retailing research: A Retrospective. Journal of Retailing 85(2), 113-128 (2009)

5. Fullerton, S., Kerch, K.B., Doger, H.R.: Consumer Ethics: An Assessment of individual Behaviour in the market place. Journal of Business Ethics 15, 805-814 (1996)

6. Muncy, J.A., Vitell, S.J.: Consumer Ethics: An investigation of the Ethical beliefs of the final consumer. Journal of Business Research 24, 297-311 (1992)

7. Strutton, D., Pelton, L.E., Ferrell, O.C.: Ethical Behaviour in Retail Settings: Is there a Generation Gap? Journal of Business Ethics 16, 87-105 (1997)

8. Vitell, S.J., Muncy, J.A.: The Muncy-Vitell Consumer Ethics Scale: A modification and Application. Journal of Business Ethics 62, 267-275 (2005)

9. Burns, D.J., Fawctt, J.K., Lanasa, J.: Business Students Ethical perceptions of Retail Situations: Amicrocultural Comparison. Journal of Business Ethics 13, 667-679 (1994)

10. Lagace, R.R., Dahlstrom, R., Gassenheimer, J.B.: The Relevance of Ethical Salesperson Behviour on Relationship Quality: The Pharmaceutical Industry. Journal of Personal Selling\& Sales Management 11, 39-47 (1991)

11. Mcintyre, F.S., Thomas, J.R., Gilbert, F.W.: Consumersegments and Perceptions of Retail Ethics. Journal of Marketing Theory and Practice 2, 43-53 (1999)

12. Roman, S.: The Impact of Ethical Sales Behaviour on Customer Satisfaction, Trust And Loyalty to the company: AnImpirical study in the financial service Industry. Journal of Business Ethics 19, 915-949 (2003)

13. Beltramini, R.F.: Application of the Unfairness Doctorine to Marketing Communications on the Internet. Journal of Business Ethics 42, 393-400 (2003)

14. Caudill, E.M., Murphy, P.E.: Consumer Online Privacy: Lgal and Ethical Issues. Journal of Public Policy and Marketing 19, 7-19 (2000)

15. Maury, M.D., Kleiner, D.S.: E-Commerce, Ethical Commerce? Journal of Business Ethics 36, 21-31 (2002)

16. Pollach, I.: A Typology of Communicative strategies in online privacy policies: Ethics,Power and informed Consent. Journal of Business Ethics 62, 221-235 (2005) 
17. Palmer, D.E.: Pop-Ups, Cookies, and Spam:Toward a Deeper Analysis of the Ethical Significance of Internet Marketing Practices. Journal of Business Ethics 58, 271-280 (2005)

18. Murphy, P.E., Laczniak, G.R., Bowie, N.E., Klein, T.A.: Ethical Marketing: Basic Ethics in Action. Pearson Prentice Hall, NJ (2005)

19. Gaski, J.F.: Does Marketing Ethics Really Have Anything to say? A critical Inventory of the Literature. Journal of Business Ethics 18(3), 315-334 (1999)

20. Pires, G.D., Stanton, J.: Ethnic Marketing Ethics. Journal of Business Ethics 36, 111-118 (2002)

21. Fisher, J., Taylor, D., Fullerton, S.: Attitudes towards consumer and Business Ethics among Canadian and NewZealand Business students: An assessment of 25 Scenarios. Journal of Business Ethics 3(2), 155-177 (1999)

22. Murphy, P.E., Laczniak, G.R., Wood, G.: An Ethical Basis for Relationship Marketing: A virtue ethics perspective. European Journal of Marketing 41(2), 37-57 (2007)

23. Vitell, S.J., Ho, F.N.: Ethical Decision making in Marketing: Asynthesis and evalution of scales measuring the various components of decision making in ethical situations. Journal of Business Ethics 16(7), 699-717 (1997)

24. Fraedrich, J.P.: Reviewed work(s): Ethics in Marketing by N. Craig Smith; John A. Quelch. Practical Business Ethics by Warren A.French; John Granrose. Journal of Marketing 60(1), 122-123 (1996)

25. Roman, S.: Relational Consequences of Perceived Deception in Online Shopping: The Moderating Roles of Type of Product, Consumer's Attitude Toward the Internet and Consumer's Demographics. Journal of Business Ethics 95, 373-391 (2007, 2010)

26. Roman, S.: The Ethics of Online Retailing: A Scale development and Validation from the Consumers' Perspective. Journal of Business Ethics 72, 131-148 (2007)

27. Roman, S., Cuestas, P.J.: The Perceptions of Consumers Regarding Online Retailers' Ethics and Their Relationship with Consumers' General Internet Expertise and Word of Mouth: A preliminary Analysis. Journal of Business Ethics 83(4), 641-656 (2008)

28. Kurt, C., Hacioglu, G.: Ethics as a customer perceived value driver in the context of online retailing. African Journal of Business Management 4(5), 672-677 (2010)

29. Limbu, Y.B., Wolf, M., Lunsford, D.L.: Consumers' perceptions of online ethics and its effects on customer satisfaction. Journal of Research in Interactive Marketing 5(1), 71-89 (2011)

30. Arjoon, S., Rambocas, M.: Ethics and Customer Loyalty: Some Insights into Online Retailing Services. International Journal of Business and Social Science 14(2), 135-142 (2011)

31. Barry, V.: Moral Issues in Business. Wadsworth Publishing Co., New York (1979)

32. Bartels, R.: A Model for Ethics in Marketing. Journal of Business Ethics 31, 20-26 (1967)

33. Beauchamp, T.L., Bowie, N.E.: Ethical theory and Business, 2nd edn. Prentice Hall, NJ (1983)

34. Sheth, J.N., Parvatiyar, A.: Relationship marketing in Consumer Markets: Antecedents and Consequences. Journal of the Academy of Marketing Science 23(4), 255-271 (1995)

35. Gremler, D.D., Brown, S.W., Gremler, D.D., Brown, S.W.: The loyalty ripples effect. International Journal of Service Industry Management 10(3), 271-291 (1999)

36. Oliver, R.L.: Whence consumer loyalty. Journal of Marketing 63(1), 33-45 (1999)

37. Cronin, J.J., Brady, J.R., Hunt, G.T.M.: Assessing the effects of quality, value, and customer satisfaction on consumer behavioral intentions in service environments. Journal of Retailing 76(2), 193-218 (2000) 
38. Garca de los Salmones, M.M., Perez, A., Rodri Guez delBosque, I.: The social role of financial companies as a determinant of consumer behaviour. The International Journal of Bank Marketing 27(6), 467-485 (2009)

39. Lafferty, B.A., Goldsmith, R.E.: Cause-brand alliance: does the cause help the brand or does the brand help the cause. Journal of Business Research 58(4), 423-429 (2005)

40. Sen, S., Bathtacharya, C.B., Korschun, D.: The role of corporate social responsibility in strengthening multiple stakeholder relationships: a field experiment. Journal of The Academy of Marketing Science 34(2), 158-166 (2006)

41. Maignan, I., Ferrell, O.C.: Corporate social responsibility and marketing: an integrative framework. Journal of the Academy of Marketing Science 32(1), 3-19 (2004)

42. McDonald, L.M., Rundle-Thiele, S.R.: Corporate social responsibility and bank customer satisfaction: a research agenda. International Journal of Bank Marketing 26(3), 170-182 (2008)

43. Balabanis, G., Reynolds, N.: Consumer attitudes towards multi-Channel retailers' Web Sites: The role of involvement, brand attitude, internet knowledge and visit duration. Journal of Business Strategies 18(2), 105-131 (2001)

44. Kim, J., Fiore, A., Lee, H.: Influence of online store perception, shopping enjoyment, and shopping involvement on consumer patronage behaviour towards an online retailer. Journal of Retailing and Consumer Services 14, 95-107 (2007)

45. Wagner, T., Bicen, P., Hall, Z.: The dark side of retailing: towards a scale of corporate social irresponsibility. International Journal of Retail \& Distribution Management 362, 124-142 (2008)

46. Sen, S., Bhattacharya, C.B., Korshun, D.: The role of corporate social responsibility in strengthening multiple stakeholder relationships. Journal of the Academy of Marketing 34, $158-166$ (2006)

47. Siu, N., Zhang, T., Yau, C.: The Roles of Justice and Customer Satisfaction in Customer Retention: A Lesson from Service Recovery. Journal of Business Ethics 114(4), 675-686 (2013)

48. Chin, W., Marcolin, B., Newsted, P.: A partial least squares latent variable modeling app roach for measuring interaction effects: Results from a montecarlo simulation study and voice mail emotion/adoption study. Paper presented at the 15th International Conference on Information Systems, Cleveland, Ohio, USA, pp. 21-41 (1996)

49. Nunnally, J.: Psychometric methods, 2nd edn. McGraw-Hill, New York (1978)

50. Wixom, B., Watson, H.: An empirical investigation of the factors affecting data warehousing success. MIS Quarterly 25(1), 17-41 (2001)

51. Bock, G.W., Zmud, R.W., Kim, Y.G., Lee, J.N.: Behavioral intention formation in knowledge sharing: Examining the roles of extrinsic motivators, social-psychological forces, and organizational climate. MIS Quarterly 29(1), 87-111 (2005)

52. Bagozzzi, R.P., Yi, Y.: On the evaluation of structural equation models. Journal of the Academy of Marketing Science 16(1), 74-94 (1988)

53. Fornell, C., Larcker, D.: Evaluating structural equation models with unobservable variables, and measurement error. Journal of Marketing Research 18(1), 39-50 (1981)

54. Gefen, D., Straub, D., Boudreau, M.: Structural equation modeling techniques and regression: Guidelines for research practice. Communications of AIS 7(7), 1-78 (2000)

55. Doll, W.J., Weidong, X., Torkzadeh, G.: A confirmatory factor analysis of the end-user computing satisfaction instrument. MIS Quarterly 18(4), 453-461 (1994)

56. Dabholkar, P.A., Thorpe, D.I., Rentz, J.O.: A measure of service quality for retail stores: Scale development and validation. Journal of the Academy of Marketing Science 24(winter), 3-16 (1996) 
57. Kline, R.: Principles and practice of structural equation modeling. The Guilford Press, New York (1998)

58. Kock, N.: Using WarpPLS in e-collaboration studies: Descriptive statistics, settings, and key analysis results. International Journal of e-Collaboration 7(2), 1-18 (2011)

59. Ellis, T.S., Griffith, D.: The evaluation of it ethical scenarios using a multidimensional scale. ACM SIGMIS Database 32, 75-85 (2001)

60. Peha, J.M., Khamitov, I.M.: Paycash: a secure efficient Internet payment system. Electronic Commerce Research and Applications 3, 381-388 (2004)

61. Hwang, R.J., Shiau, S.H., Jan, D.F.: A new mobile payment scheme for roaming services. Electronic Commerce Research and Applications 6, 184-191 (2007)

62. Kim, C., Tao, W., Shin, N., Kim, K.S.: An empirical study of customers'perceptions of security and trust in e-payment systems. Electronic Commerce Research and Applications 9, 84-95 (2010)

63. Lim, A.S.: Inter-consortia battles in mobile payments standardisation. Electronic Commerce Research and Applications 7, 202-213 (2008)

64. Parasuraman, A., Zeithaml, V.A., Malhotra, A.: E-S-QUAL A Multiple-Item Scale For Assessing Electronic Service Quality. Journal of Service Research 7, 213-233 (2005)

65. Wolfinbarger, M., Gilly, M.C.: eTailQ: Dimensionalizing, Measuring and Predicting etail Quality. Journal of Retailing 79, 183-198 (2003)

66. Ben-Ner, A., Putterman, L.: Trust in the New Economy. In: Jones, D.C. (ed.) New Economy Handbook, pp. 1067-1095. Academic Press, New York (2003)

67. DePaulo, B.M.: NonverbalBehavior and Self-presentation. Psychological Bulletin 111, 203-243 (1992)

68. Lichtenstein, D.R., Drumwright, M.E., Braig, B.M.: The effect of corporate social responsibility on customer donations to corporate supported non-profits. Journal of Marketing 68(9), 16-32 (2004)

69. Holland, D., Albrecht, C.: The Worldwide Academic Field of Business Ethics:Scholars' Perceptions of the Most Important Issues. Journal of Business Ethics 117, 777-788 (2013)

70. Collier, J.E., Bienstock, C.C.: Measuring service quality in e-retailing. Journal of Service Research 8, 260-275 (2006)

71. Stead, B.A., Gilbert, J.: Ethical Issues in Electronic Commerce. Journal of Business Ethics 34, 75-85 (2001)

72. Truste, TN's/Truste Holiday (2005), http: / / www.truste.org/about/press_release/

73. Wolfinbarge, M., Gilly, M.C.: eTailQ: Dimensionalizing, Measuring and Predicting etail Quality. Journal of Retailing 79, 183-198 (2003)

74. Roman, S., Ruiz, S.: Relationship Outcomes of Perceived Ethical Sales Behavior: The Customer's perspective. Journal of Business Research 58, 439-445 (2005)

75. Norris, D.G., Gifford, J.B.: Retail Store Managers and Students perceptions of Ethical Retail Practices? A comparative and Longitudinal Analysis. Journal of Business Ethics 7, 515-524 (1988)

76. LeMenestrel, M., Hunter, M., DeBettignies, H.C.: E-Ethics in Confrontation with an Activities Agenda: Yahoo on Trial. Journal of Business Ethics 39, 135-144 (2002)

77. Sama, L.M., Shoaf, V.: Ethics on the web: Applying Moral Decision-Making to the New Media. Journal of Business Ethics 36, 93-103 (2002)

78. Siplor, J.C., Ward, B.T., Rongione, N.M.: Ethics of collecting and using consumer internet Data. Information System Management 21, 58-66 (2004)

79. Stead, B.A., Gilbert, J.: Ethical issues in electronic commerce. Journal of Business Ethics $34,75-85$ (2001) 
80. Hunt, S., Vitell, S.: A General Theory of Marketing Ethics. Journal of Macromarketing 1(1), 5-16 (1986)

81. Nardal, S., Sahin, A.: Ethical issues in e-commerce on the basis of online retailing. Journal of Social Sciences 7(2), 190-198 (2011)

82. Holden, R.K.: An exploratory study of trust in buyer \pm seller relationships. A Dissertation. University Microfilms International, ANN Abor (1990)

83. Fornell, C., Larke, D.: Evaluating structural equation models with unobservable variables and measurement error. Journal of Marketing Research 18(1), 39-50 (1981)

84. Chin, W.: Overview of the PLS method (1997), http: / / discnt.cba.uh.edu/chin/PLSINTRO.HTM

85. Vesel, P., Zabkar, V.: Managing Customer Loyalty through the Mediating Role of Satisfaction in the DIY Retail Loyalty Program. Journal of Retailing and Consumer services 16(5), 396-406 (2009)

86. Anderson, E.W., Sullivan, M.W.: The antecedents and consequences of customer satisfaction for firms. Marketing Science 12(2), 125-143 (1993)

87. Bolton, R.N.: A dynamic model of the duration of the customer's relationship with a continuous service provider: the role of satisfaction. Marketing Science 17(1), 45-65 (1998)

88. Cronin, J.J., Taylor, S.A.: Measuring service quality: a reexamination and extension. Journal of Marketing 56(3), 55-68 (1992)

89. Fornell, C.: A national customer satisfaction barometer: the Swedish experience. Journal of Marketing 56(1), 6-21 (1992)

90. Oliver, R.L.: A cognitive model of the antecedents and consequences of satisfaction decisions. Journal of Marketing Research 17, 460-469 (1980)

91. Patterson, P.G., Spreng, R.A.: Modelling the relationship between perceived value,satisfaction and repurchase intentions in a business-to-business, services context: an empirical examination. International Journal of Service Industry Management 8(5), 414-434 (1997)

92. Rust, R.T., Zahorik, A.J.: Customer satisfaction, customer retention and market share. Journal of Retailing 69(2), 193-215 (1993)

93. Kousaridas, A., Parissis, G., Apostolopoulos, T.: An open financial services architecture based on the use of intelligent mobile devices. Electronic Commerce Research and Applications 7, 232-246 (2008)

94. Palmer, A., Beggs, R., Keown-McMullan, C.: Equity and repurchase intention following service failure. Journal of Services Marketing 14, 513-528 (2000)

95. Maignan, I.: Consumers' perceptions of corporate social responsibilities: a cross-cultural comparison. Journal of Business Ethics 30(1), 57-72 (2001)

96. Vijayan, J.: Security Concerns Cloud Online Shopping. Computerworld, 5-8 (December 2005) 